\title{
Spatial Thinking or Thinking Geographically? On the Importance of Avoiding Maps without Meaning
}

\author{
Anke UHLENWINKEL \\ Potsdam/Germany·uhlenw@uni.potsdam.de \\ This contribution was double-blind reviewed as full paper.
}

\begin{abstract}
It is widely accepted that to produce a map students need to be able to think spatially. This article does not question the importance of spatial thinking, but it argues that to produce a geographically sound map, that is a map that does not only show where things are, but that tries to answer a geographical question, it is also relevant to be able to think geographically. In its empirical part it shows that students who are half-way through their studies to become teachers often lack this ability which inevitably has repercussions for school geography.
\end{abstract}

\section{Introduction}

In December 1989 the psychologist JEROME BRUNER held a lecture at Jerusalem University in which he claimed that the Cognitive Revolution had somehow missed its aim. Having been conceived as an answer to the behavioural approach that locked thinking into a black box and only observed the inputs and outputs of the process, the Cognitive Revolution sought to put an emphasis on the workings inside the black box that is on the process of thinking itself. With the advent of the digital era this effort soon turned into the study of information processing rather than meaning-making, thereby losing part of its original attraction and also opening doors for a renewed behavioural perspective (BRUNER 1990).

In this paper I claim that similar differences can be observed in the discussion on map production especially in the context of the usage of geographic information systems. Interestingly enough in the English-speaking world these differences seem to have a regional component: while in American English there is a broad discussion on spatial thinking, in British English the focus is on thinking geographically. While the first term can be associated to information processing, the second term encompasses meaning-making. In the debates on Geographic Information Systems (GIS) there is a strong focus on spatial thinking only, which may lead to perfect maps that have nothing to say. I will argue that, to avoid such outcomes, the competence of thinking geographically has to be given more attention in this field. To do this, I will first discuss the theoretical content of the two terms respectively and then take a closer look at difficulties German university students who are studying to become teachers had when asked to draw a map on a given topic. 


\section{Spatial Thinking and/or Thinking Geographically}

\subsection{Spatial Thinking}

In the US the term spatial thinking has been defined and promoted by a report of the National Research Council entitled 'Learning to Think Spatially. GIS as a support system in the K-12 curriculum' (NATIONAL RESEARCH COUCIL (NRC) 2006). The report shows a certain formal similarity to the present paper as it also starts with an example taken from an article by JEROME BRUNER published in 1959. In this paper BRUNER describes two geography classes: one that learned facts about "arbitrary cities at arbitrary places by arbitrary bodies of water and arbitrary sources of supply" and another that "learned geography as a set of rational acts of induction - that cities spring up where there is water, where there are natural resources, where there are things to be processed and shipped" (1959, quoted in NRC 2006, 11). The first example he sees as pure rote learning, while in the second he detects active thinking, as the children are encouraged to make up stories that explain why certain cities are located at certain places before they compare their results to reality. This approach is very much in line with the High School Geography Project of the AAG (GRAVES 1971) and can also be seen as the origin for what later became a narrative approach (BRUNER 1990).

In the NRC report it is seen as an example for spatial thinking, that in turn is understood as one way of thinking among others, such as verbal, logical, metaphorical, hypothetical, mathematical or statistical thinking (NRC 2006: 12). In this context spatial thinking is defined by three components: the concept of space, different modes of representation and the justification of choices made. Of these three components it is the concept of space that distinguishes spatial thinking from other forms of thinking. Space itself is defined by its properties such as dimensionality, continuity, proximity and separation, all of which make it measurable in terms of kilometres or miles, time distances or with reference to different coordinate systems. Clearly, although these properties do have a certain affinity to a number of modern geographical concepts, they mirror a more geometrical perspective that was characteristic for geographical thinking in the era of early spatial sciences (WARDENGA 2002; LAMBERT \& MORGAN 2010). It is therefore not surprising, that the example used for demonstrating spatial thinking in geography is one of the outstanding achievements from this era: CHRISTALleR's Central Place Theory. Based on his observations in southern Germany, CHRISTALLER set out to explain the location of different towns without relating to specific characteristics of their sites as for example rivers or roads. Instead he developed a generic system that can be seen to make use of a number of different spatial approaches such as "space as in graphics, space as in the description and analysis of patterns, space as in a structure for a model, and space as in algebraic relations in the form of hierarchies" (NRC 2006, 91). The resulting model showed strict geometrical patterns that for CHRISTALLER were correct in themselves regardless of whether they could be found in reality or not. It seems to have been these geometrical patterns that inspired WILLIAM BUNGE's statement "that the initial and growing beauty of central place theory is geography's finest intellectual product", a quote which the NRC uses as a concluding remark for the section on spatial thinking in geography (1966, quoted in NRC 2006, 93).

The example of ChristalleR's Central Place Theory seems slightly at odds with the illustration taken from BRUNER: While BRUNER stresses the importance of meaning-making 
through relating locations to certain conditions, CHRISTALLER tries to find spatial laws that need not refer to any meaning. Instead they simply process information and in that respect they are quite compatible with GIS-technologies. Unfortunately it is exactly this meaninglessness that makes the approach prone to be used for questionable political ends. CHRISTALLER himself is proof of this: At the beginning of World War II he joined the planning department of the SS (Stabshauptamt Planung und Boden im SS-Planungsamt Reichskommisariat für die Festigung deutschen Volkstums), which later gave him the opportunity to use his model to reorganize Polish territory conquered by Germany (RÖSSLER 1987). What fascinated the Nazis about the model was the hierarchical structure and its sense of leadership as well as the idea of 'Volksgemeinschaft' (national community) that they felt was embodied in it (WARDENGa, HenNiges, Brogiato \& SchelhaAs 2011). This is not to say that CHRISTALLER's model was fascist in itself. Far from it, it was also used as a tool for regional planning in West Germany in the 1960s and 1970s (e.g. KLUCZKA 1970) and the Dutch based the distribution of the settlements on one of their newly-built polders on it (PALINGS 2009). Nevertheless, to find out whether or not it is applied responsibly, one also has to consider the social purposes it is used for and the power constellations that enforce them. This is implied in the notion of thinking geographically.

\subsection{Thinking geographically}

The term thinking geographically denotes a decidedly subject-based idea. People who think geographically use geographical concepts which in turn define the geographical perspective. The meanings as well as the choice of the key and organizing concepts are constantly changing (TAYLOR 2008) and also differ between authors. Considering only a span of four years JACKSON (2006) names space and place, scale and connection, proximity and distance as well as relational thinking as important concepts in geography, TAYLOR (2008) uses the key concepts place, space and time supplemented by the organizing concepts diversity, interaction, perception and representation as well as change while LAMBERT and MORGAN (2010) refer to space, place, scale, interdependence and development, cultural understanding and diversity as well as environment, sustainability and future. Despite the use of partly different terms and the diversity of compilations there are a number of similarities as, for example, the focus on place and space as key concepts. Considering only the concept of space for comparative reasons it is easy to detect some variations in the definition of space in the context of spatial thinking and in the context of thinking geographically. Most British authors follow DOREEN MASSEY in her conception of space (MASSEY 2005). She sees spaces as the outcome of commonly hard to discern interdependencies between places. The concept of space therefore cannot be conceived without the concept of place. Consequently, spaces are perceived as an assemblage of numerous trajectories being simultaneously followed in different places and influencing each other, thereby initiating change in the different places and spaces, respectively. Who influences whom, in what way, and to which ends, are questions of the underlying power geometries (MASSEY 1999) that constantly reshape the world. Hence, spaces are not stable, but always stories-so-far. The concept is thus in line with modern constructivist approaches.

While in Britain there is a lively theoretical debate on thinking geographically, the French have developed a completely new map culture based on a similar approach. Focussing on the concept of space cartographers usually use a variant of BRUNET's matrix of symbols (BRUNET 1997) to create their maps, called croquis. In contrast to a map that is defined as a 
simplified representation of the surface of the earth, a croquis is understood as a simplified representation of space aiming to explain its organisation (REVERT 2012). If you compare the French croquis with thematic maps from a German atlas, you can clearly see how the concepts of thinking geographically and spatial thinking make a difference. Figure 1 shows a French croquis of Brazil that has been used to prepare school students for their final examination (JALTA, JOLY \& REINERI 2008). At first glance it appears to be very simple and easy to read. But when looking at the two keys below the map a different story is revealed. There are two features that seem of fundamental importance: First, although the colouring appears as little detailed it does aggregate different data (population density, economic activities) and links them to the notions of centre and periphery. Consequently it is not facts that are shown but a conceptually guided classification. Second, the two keys combine the same symbols in two different ways to answer two slightly different geographical questions: Which are the most developed regions? Which are the least developed regions? These questions point to a regional problem that the map wants to address: the identification of the potential for further development or of regions lagging behind respectively. This procedure corresponds to a conceptual approach that understands concepts as acts of thinking that aim to identify and solve problems (DELEUZE \& GUATTARI 1991). Unlike the French croquis, a corresponding map from a German atlas (Diercke) gives the impression to be much more detailed, which is mainly due to the small-scale representation of living conditions in Brazil. The key itself is much less detailed than that of the croquis: it only shows three different aspects (living conditions, migration flows and net migration by federal states and territories), two of which are more or less redundant. Thus, while the German map appears to be more detailed and more difficult to read, it actually features less information than the French croquis.

This astonishing difference is due to the circumstance that - contrary to traditional thematic maps - the French croquis do not simply show the regional distribution of facts, but integrate a geographical perspective into the maps. This does not mean that traditional thematic maps are superfluous; very often they are even the basis from which croquis are developed (REVERT 2012). But a croquis also always offers an interpretation of the data that the reader has to decode. The explicit integration of interpretation into the map itself exposes it as a product of the human mind and implies a certain provisional nature of the statements made. The maps thus can be seen as telling stories-so-far, which has prompted one famous French cartographer to write a very short essay entitled 'Praise of Sketches' (REKACEWICZ 2009) in which he warns against all too perfect technically produced maps that convey a sense of objectivity that they cannot meet.

This statement implies that to produce a convincing geographical map it is necessary, yet not sufficient to acquire spatial thinking. What is needed on top of it is to be able to think geographically. In other words, spatial thinking needs to accompany geographical thinking and is an expression of the geographical discourse, not the discourse itself (REVERT 2012). 


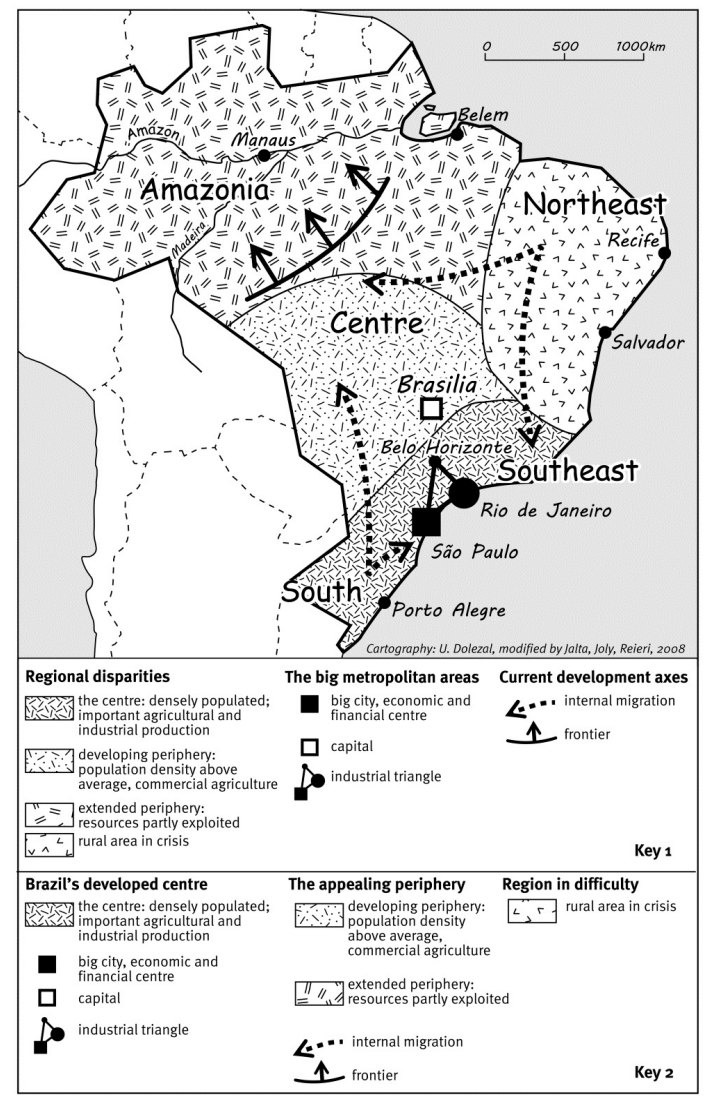

Fig. 1:

French croquis showing disparities in regional development (based on JALTA et al. 2008, 44 and 45)

\subsection{An example}

On its website the British Ordnance Survey offers a number of teaching materials not only concerned with understanding maps, but also GIS. These GIS missions represent welldeveloped proposals in the field, and they can also be used to demonstrate the difference between spatial thinking and thinking geographically.

At the outset of the mission 'Wind Power Location' the students are told that demand for renewable energy is rising, but that finding appropriate sites to build wind farms is not easy. They are then asked to choose three possible sites out of five considering five locational factors: availability of land, wind conditions, distance from settlement, distance from protected areas and ease of access. Each of these factors is shown in a different map layer that students can turn on and off. Besides these layers there are three other ones: one for the five possible sites, one for contours and one for 'other local features' such as forest areas, a quarry, a campsite and a TV/radio mast. Neither the contours nor the other local features are of any importance for the score a site can reach. Equally unimportant are the descriptions of places that pop up when you click on the boxes labelled either ' $i$ ' for information or ' $p$ ' for protected areas, that contain information on the people living in the different villages and their attitudes towards wind power as well as details on protected historical buildings or species. Decision-making is thus restricted to measurable locational 
factors, to questions of proximity and distributional patterns of the different factors. According to the definitions above this would be a decision based on spatial thinking. However, scoring remains rather subjective as there are no criteria as to when something is close or not. But this difficulty can be solved inside the framework of spatial thinking. Another problem is not as easily solved. When you complete the mission, your choices are rated and here other aspects are taken into consideration. For one of the less favourable sites students are told, that building a wind farm here 'is likely to cause major protests from local people'. Interestingly enough, opposition to wind farms in this mission is strongest with wealthy retired people and commuters, while quarry workers and the people from a village with a high unemployment rate are less critical. For another lesser site it is argued, that 'the RSPB are concerned that turbines could result in reduced numbers of Ring Ouzel and Pied Flycatcher', while in relation to the site that is considered a 'great choice' students are informed that 'the Peregrine Falcons will hopefully not be affected too much by the turbines on the other side of the hill'. Both of these examples mark exactly the point where geographical thinking sets in. The question that has to be answered here is 'Who decides on who gets what, where and why?' (GARDNER \& BOIX-MANSILLA 2006, LAMBERT \& MORGAN 2010). It cannot be answered by mere scoring or measuring proximities. For example the nesting places of the Peregrine Falcon are situated in a Site of Special Scientific Interest, that are judged as the most sensitive to wind farms from the point of view of bird specialists (PERCIVAL 2009). Hence, if you constructed the whole GIS mission around the point of view of bird lovers and biologists the outcomes would be different, because you would have to use a different set of criteria, such as direct loss of nesting places, disturbances and risk of collision. The actual and the potential GIS missions require spatial thinking as they ask students to compare distances and evaluate patterns. Geographical thinking would include considering the point of view of the GIS mission as well as considering social, economic, cultural and environmental ideas that lead to places and spaces being made, maintained and contested.

\section{Some Empirical Findings on Student Teachers' Competences to Think Geographically}

Taking BRUNER's remarks both the earlier ones from 1959 and the later ones from 1990 into account it can be assumed that in the information age students of all age groups may find it difficult to detect and produce geographical meaning in the sense of French geography, especially as the question is not only whether or not they can attribute meaning to a place, but whether they can attribute meaning to a set of data and develop a geographical theory.

University student who are studying to become teachers are vital to disseminating knowledge and competences. It is at this period of their lives that teachers are most exposed to theoretical ideas and concepts. If they want to develop the ability to think geographically, this is the time when they can most easily acquire support. But if this support is insufficient, it may have stronger repercussions on geography teaching at schools than at any other times in the professional lives of teachers. Therefore, it seems sensible to determine what levels of geographical thinking student teachers reach during their university studies. To do this an empirical study involving BA-students at the end of their course was conducted. 
The topic the students were asked to work on was the development of tourism in the Algarve (Portugal). The Algarve is a rather typical tourist destination and its story-so-far can be seen as similar to stories that can be told of other tourist regions. Hence, students could use geographical theory to interpret the data they were given. These included seven maps, a diagram and a table showing different aspects of tourist development from road infrastructure and camping as well as hotel capacities to rural tourism, nature parks and data on climatic differences along the coastline. On the basis of these data and an information sheet showing map symbols usually used at BAC-level in France, the students were required to produce a croquis on the topic. If they wanted to they could have used the Internet for further information, but hardly anyone made use of this opportunity and those few who did, did so rather randomly without trying to answer any enquiry-based questions.

In total, 29 croquis were collected from different courses. It was not the explicit aim of these courses to teach 'thinking geographically', but how to teach geography and in that context also how to teach geographical thinking. The course therefore intended to build on what has been or should have been taught in academic geography. Of course, the contexts in which the croquis were produced were not always identical. There were variations because of slightly different ways to approach the concept of a croquis and because of the discussions that followed from the presentation. These differences minimized the probability that the results are mainly due to the way of teaching (MILLAR 2005). This is important as the aim of the study was not to evaluate teaching and learning processes, but to describe the actual competences of the student teachers no matter how they acquired them.

The croquis were analysed using a declination of the command word 'describe' based on Bloom's taxonomy (ROBERTS 2003). This approach differs from the understanding in the German speaking geography education community where each command word is ascribed to one or two levels of the taxonomy, i.e. describe would be seen as belonging to the levels of knowledge and comprehension only. Hence, the levels of application, analysis, synthesis or evaluation could not be achieved through description. To test these higher levels you would have to ask students to explain certain phenomena, for example. As this system distinguishes different levels of the taxonomy by the qualities of the thinking processes implied in each command word, it is difficult to use when trying to measure student achievements. ROBERTS takes the qualitative characteristics of the command words into account and identifies levels of thinking for each of them separately. This approach facilitates the evaluation of the work produced by students (or others). For the purpose of the evaluation of the croquis ROBERTS' declination of the command word 'describe' has been slightly modified (Tab. 1). Description here starts with the simple reproduction of information (knowledge). On the next higher level of thinking (comprehension), it is extended by the ability to use new information and express it in one's own words. The level of application includes the capability to classify information to produce integrated descriptions of a complex reality. This implies the use of theoretical concepts in order to be able to know which classifications are feasible. In the croquis of Brazil the agglomerations have been classified into the capital, the industrial triangle, big cities and the others (not mentioned in the key). In addition to this the level of analysis asks for the ability to relate data to each other and find similarities and differences using the classifications that have been created before. At this level, aggregates of the regional differences (as shown in the croquis of Brazil) may be developed. The complete croquis then shows the synthesis, which requires students to integrate all the relevant information to form their own conceptual understanding of the topic in question. This is usually done by answering a complex ques- 
tion or solving a problem. The highest level of thinking is a rather general one and can be applied to different command words. It basically covers some of the important skills needed in critical thinking (COTTRELL 2005, VAN DEN BRINK-BUDGEN 2010), for example to be able to identify open questions, to evaluate the sources used, including a judgement of the arguments made (if any) and to name additional information that might be needed to reach more conclusive results. This last level has not been considered in this study as it is hard to detect these skills in a drawn document.

Table 1: Levels of thinking relating to the command word 'describing' (based on ROBERTS 2003, 113)

\begin{tabular}{|l|l|}
\hline \multicolumn{2}{|c|}{ Describing } \\
\hline knowledge & using information that has been learned before, including definitions of terms \\
\hline comprehension & $\begin{array}{l}\text { using new information from different media and present it in your own } \\
\text { words }\end{array}$ \\
\hline application & classifying information and linking it to theoretical and conceptual ideas \\
\hline analysis & $\begin{array}{l}\text { finding relevant information and relating it to other information by showing } \\
\text { e. g. similarities and differences }\end{array}$ \\
\hline synthesis & $\begin{array}{l}\text { integrating information and developing a conceptual idea of the topic in } \\
\text { question }\end{array}$ \\
\hline evaluation & $\begin{array}{l}\bullet \quad \text { questioning sources } \\
\text { identifying blind spots in the presentation } \\
\text { specify missing information }\end{array}$ \\
\hline
\end{tabular}

The 29 croquis have been independently assessed by two people. Afterwards the results were compared. Most of the assessments were consistent with each other. In some cases where there were differences the ensuing discussion led to a more differentiated understanding of the levels of thinking in relation to the croquis. The classification of one of the croquis as belonging to the level of synthesis was later discussed with a third colleague and reviewed. In consequence of this revision there are no croquis that were classified as showing synthesis leaving this category empty.

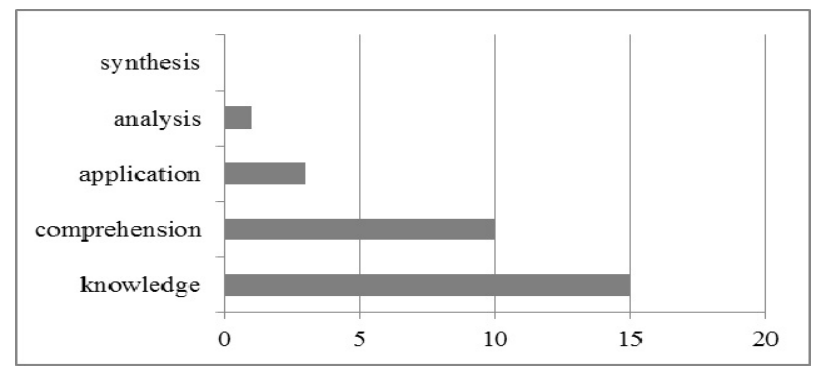

Fig. 2: Students' achievement in croquis production 
In the croquis that were classified as showing only knowledge, students tried to integrate as much discrete information as possible into one map. An extreme example of this procedure was produced by one of the male students. He handed in a technically perfect looking digital map that simply reproduced the information he had been given (Fig. 3). Another extreme example was offered by a student who simply cut out all the original maps, glued them onto a new sheet of paper adding a headline ('Development of the Algarve') and three contour maps, one of the world, Europe and Portugal, respectively. The majority of croquis that were seen to belong to this category showed a limited number of facts usually taken from one or two of the sources provided. These differences notwithstanding, all the croquis in this category simply reproduced the facts that could be found in the material. Fifteen out of the 29 croquis were assigned to this level of thinking (Fig. 2).

The authors of the croquis contained in the category of comprehension at least partially tried to represent the data 'in their own words'. Very often the students used a diagram showing the number of tourists in different towns for the month of August in three consecutive years. Although - because of the limited time spans (only one month and only over three years) - this diagram is not really suitable to give any information on the development of tourism in the Algarve it was used for just that. With the help of the diagram students tried to determine increases and decreases in tourism, usually represented by upward or downward pointing arrows, a way of symbolizing meaning that is adequate for croquis. Yet, the geographical thinking behind the symbolisation was deficient as students tried to derive the 'answer' to the question of how tourism developed in the Algarve, as directly as possible from the material they were given: they simply looked out for that bit of information that would directly provide them with the solution. This may not be surprising considering how geography is taught in German schools, but it led to a misjudgement of the source as it can at best tell the places that are most popular with tourists. It can hardly tell anything about a long term development of tourism as was requested. This misinterpretation notwithstanding, ten of the 29 croquis were classified as showing comprehension as the students at least tried to do a little more than just reproduce the data.

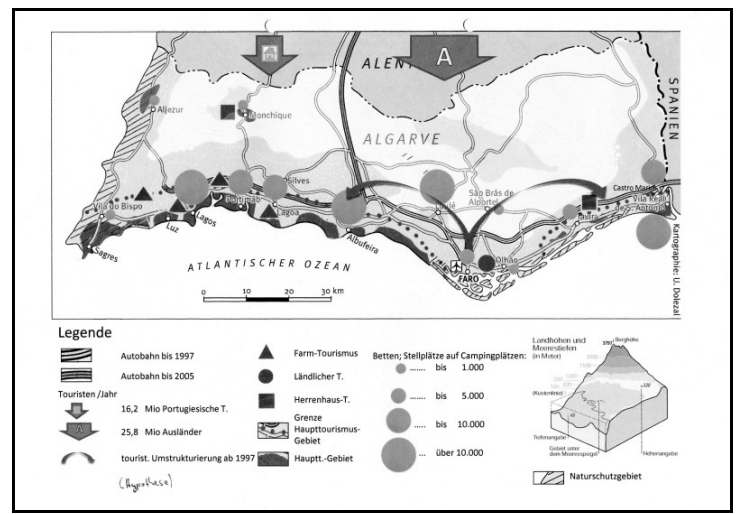

Fig. 3: A perfect map, showing only low levels of 'thinking geographically' 
With 25 croquis falling into the first two categories there were only four left that could be classified as showing either application or analysis. Of these three were categorized as application. Students whose croquis fell into this category usually classified the two different groups of tourists (Portuguese and international) that could be assigned to different kinds of accommodation, camping and hotels. Unfortunately though, they did not use this information to generate a regional model of similarities or differences in tourist development.

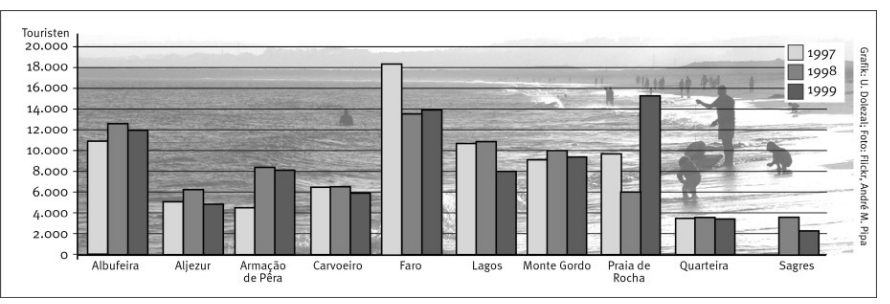

Fig. 4: Number of tourists in August (1997-1999) (source: BERENS \& BISCHOF 2001)

This was at least tried by the students who produced the only croquis that was classified as analysis. This croquis looked totally different from all the others as it did not show facts, but degrees of tourist development that were then attributed to the presence or absence of international tourist. It at least showed an effort at analysis, although that analysis could have been still more profound.

Summarising the results it was shown that only a small part (around 14\%) of the students involved in this study were able to think geographically at the end of their BA-course. Half of them only reproduced the information provided and one third at least tried to represent an idea in their own words. This outcome seems rather frustrating considering they have all had geography lessons at school, have finished the first half of their studies (in Germany, to become a teacher students have to do their BA and MA) and will soon start teaching geography themselves. The results also show that introducing croquis alone does not make geographical thinkers. This is underpinned by evidence from France that shows that students may learn to draw croquis without learning to think conceptually (DELEPLACE \& NiClOT 2005). Helped by the appropriate publications for the preparation of their BAC (e.g. DELMAS \& STARY 2007) they simply learn the croquis by heart as they would learn any other core knowledge.

\section{Conclusion}

Today drawing a technically perfect map is not a big problem (MARTIN in print). This is also true for croquis. There are a number of tools on the French-speaking web that help students and teachers to produce technically perfect croquis. Even PowerPoint can be used to achieve that. The language of croquis may or may not be difficult, but is has to be understood. It is, if you like, an academic language that does not just reproduce, but categorises, compares, analyses and summarises. It is also the language of geography. Therefore, profound geographical thinking is needed to produce a croquis. If students did not learn how to think geographically, they would not be able to produce a croquis them- 
selves. They can always reproduce croquis from their memories as is suggested by the French experience. They can also understand the methodology of producing a croquis without being able to go beyond reproducing data. This could be observed in the different BA courses that put more and more emphasis on the thorough introduction of croquis without any changes in the final results. This suggests that to be able to draw their own croquis, and to draw meaningful croquis, students need to have an understanding of geographical thought.

Hence, in order to be able to teach and learn how to produce a croquis both teachers and students need to be trained to think conceptually, which - with regard to the discipline of geography - means to think geographically. To achieve that, it is not enough to start working with croquis. Their introduction has to go hand in hand with the use of teaching strategies that help students think geographically and make meaning of the maps they use and produce. As a starting point strategies as those conceived in the Thinking Through Geography project (LEAT 1998) can be used. But as these are general thinking strategies used in geography they have to be underpinned by geographical thought.

In his 1959 text JEROME BRUNER has given a second example:

'In a social studies class of an elementary school in a well-to-do suburb of one of our great eastern cities, I saw groups of twelve-year-old children doing a 'project' on the southeastern states. Each team was gathering facts that might eventually end up on a map or a chart or some other graphic device. The fact-gathering was atomized and episodic. Here were the industrial products of North Carolina. There was the list of the five principal cities of Georgia. I asked the children of one team what life would be like and what people would worry about in a place where the principal products were peanuts, cotton, and peaches. The question was greeted as 'unfair'. They were gathering facts' (BRUNER 1959: 188).

What Bruner is asking for here is geographical thinking. And it seems it still needs to be asked for today.

\section{References}

Berens, K. \& Bischof, M. (2001), Tourismus am Algarve. In: De LANGe, N. \& Tobias, W. (Eds.), Stadt- und Regionalentwicklung in Portugal. Ausarbeitungen zu einem Studienprojekt. Osnabrücker Studien zur Geographie, 177-191

BRUner, J. (1959), Learning and Thinking. Havard Educational Review, 29 (3), 184-192.

BRUNER, J. (1990), Acts of Meaning. Havard University Press, 181 p.

BRUnet, R. (1997), La carte-modèle et les chorèmes. In: BrunET, R. (Ed.), Champs et contrechamps. Raisons de géographe. Belin, 204-211.

CotTrell, S. (2005), Critical Thinking Skills. Palgrave Macmillan, 250 p.

Deleplace, M. \& Niclot, D. (2005), L'apprentissage des concepts en histoire et en géographie. Enquête au collège et au lycée. Scérén, $150 \mathrm{p}$.

Deleuze, G. \& GuAtTARI, F. (1991), Qu'est-ce que la philosophie? Les Éditions de Minuit, $219 \mathrm{p}$.

Delmas, J.-C. \& STARY, B. (2007), Croquis et schémas. Géographie. Belin, 160 p.

GARDNER, H. BoIX-MANsilla, V. (2006), Teaching for Understanding in the Disciplines - and Beyond. In: GARDNER, H. (Ed.), Development and Education of the Mind: the Selected Works of Howard Gardner. Routledge, 145-158 
Graves, N. J. (1971), Das "High School Geography Project" der "Association of American Geographers”. In: Schultze, A. (Ed.), Dreißig Texte zur Didaktik der Geographie. Westermann, 132-139.

JACKSON, P. (2006), Thinking Geographically. Geography, 91 (3), 199-204.

JALtA, J., Joly, J.-F. \& REINERI, R. (2008), Les croquis et les schémas du BAC. Magnard, $72 \mathrm{p}$.

KLuczKA, G. (1970), Zentrale Orte und zentralörtliche Bereiche mittlerer und höherer Stufe in der Bundesrepublik Deutschland. Forschungen zur Deutschen Landeskunde, $151 \mathrm{p}$.

LAmBerT, D. \& Morgan, J. (2010), Teaching Geography 11-18. A Conceptual Approach. Open University Press, $180 \mathrm{p}$.

LEAT, D. (1998), Thinking Through Geography. Chris Kington Publishing, 176 p.

MARTIN, F. (in print), Kartierung mithilfe Geographischer Informationssysteme. In: Rolfes, M. \& Uhlenwinkel, A. (Eds.), Metzler Handbuch 2.0 Geographieunterricht. Westermann

MASSEY, D. (1999), Power-geometries and the politics of space-time (Hettner-Lecture 1998). Department of Geography, University of Heidelberg, $112 \mathrm{p}$.

MASSEY, D. (2005), For space. Sage, 232 p.

MillaR, R. (2005), Evaluating educational programmes: Issues and perspectives. In: Bennett, J., Holman, J., Millar, R. \& Waddington, D. (Eds.), Making a Difference. Evaluation as a Tool for Improving Science Education. Waxmann, 15-32-

NATIONAL Research Council (NRC) (2006), Learning to Think Spatially. GIS as a support system in the K-12 curriculum. National Academies Press, 313 p.

Palings, H. (2009), Flevoland: die "jüngste” Region der EU. Praxis Geographie, 39 (4), 22-26.

Percival, S. (2009), Predecir los efectos de los parques eólicos sobre las aves en el Reino Unidos: el desarrollo de un método de evaluación objectivo. In: DE LUCAS, M., JANSS, G. F. E. \& FERrER, M. (Eds.), Aves y parques eólicos. Valoración del riesgo y atenuantes. Quercus, 145-162.

ReKacewicz, P. (2009), Lob der Skizze. In: Le Monde Diplomatique (Ed.), Atlas der Globalisierung. taz, 100-101.

ReVErt, S. (2012), Petite méthodologie de la cartographie. Ellipses Édition, 123 p.

RoBerTs, M. (2003), Learning Through Enquiry. Making Sense of Geography in the Key Stage 3 Classroom. Geographical Association, 212 .

RÖSSLER, M. (1987), Die Institutionalisierung einer neuen Wissenschaft im Nationalsozialismus: Raumforschung und Raumordnung 1935-1945. Geographische Zeitschrift, 75 (3), 177-193.

TAYLOR, L. (2008), Key concepts and medium term planning. Teaching Geography, 33 (2), $50-54$

VAn DEN BrinK-Budgen, R. (2010), Advanced Critical Thinking Skills. Howtobooks, $152 \mathrm{p}$.

WARDENGA, U. (2002), Alte und neue Raumkonzepte für den Geographieunterricht. geographie heute, 23 (200), 8-11.

Wardenga, U., Henniges, N., Brogiato, H. P. \& SchelhaAs, B. (2011), Der Verband deutscher Berufsgeographen 1950-1979. Eine sozialgeschichtliche Studie zur Frühphase des DVAG. Leibniz Institut für Länderkunde, 136 p. 